\title{
Pengaruh Penempatan Kerja, Disiplin kerja, dan Kompensasi Terhadap Kinerja Karyawan PT. Bank Tabungan Negara (Persero) Tbk Cabang Palembang
}

\author{
Agusri \\ STIE SERASAN Muara Enim \\ email : agusri123@gmail.com
}

\begin{abstract}
ABSTRAK
Penelitian ini bertujuan untuk mengetahui pengaruh penempatan kerja, disiplin kerja serta kompensasi terhadap kinerja karyawan PT. Bank Tabungan Negara (persero) Tbk. Kantor cabang Palembang. Rumusan masalah adalah apakah terdapat pengaruh penempatan kerja, disiplin kerja serta kompensasi terhadap kinerja karyawan? Data yang digunakan dalam penelitian ini berupa data primer dari jawaban 103 responden. Model analisis yang digunakan regresi linear berganda dan melalui pengujian instrumen validitas dan reliabilitas. Uji karakteristik data yaitu uji normalitas dan uji model terdiri dari uji multikolinearitas dan uji heterokesdatisitas. Hasil pengujian regresi linear berganda menunjukkan terdapat pengaruh positif dan signifikan penempatan kerja, disiplin kerja serta kompensasi secara simultan dan parsial terhadap kinerja karyawan PT. Bank Tabungan Negara (persero) Tbk. Kantor cabang Palembang.
\end{abstract}

Kata kunci : Penempatan Kerja, Disiplin Kerja, Kompensasi, Kinerja.

\section{A. Latar Belakang}

Aset perusahaan berupa sumber daya manusia merupakan suatu kegiatan mengelola atau mengendalikan dan mengatur sumber daya manusia dan diartikan juga sebagai keseluruhan proses perencanaan, pengorganisasian, pengarahan, dan pengawasan terhadap kegiatan seleksi, pelatihan dan penempatan, pemberian kompensasi, pengembangan, pengintergrasian, dan pelepasan SDM untuk tercapainya berbagai tujuan individu, masyarakat, pemerintah dan organisasi. Beberapa faktor yang mempengaruhi kinerja individu tenaga kerja yaitu kemampuan, motivasi, dukungan yang diterima, keberadaan pekerjaan yang mereka lakukan (kepuasan kerja) dan hubungan dengan organisasi. (Robert, 2012). Perusahaan dan karyawan memiliki sifat mutualisme yang saling membutuhkan, karena karyawan yang berkinerja dapat membawa kemajuan bagi perusahaan dan menguntungkan kedua belah pihak. Untuk peningkatan kinerja karyawan, perlu adanya faktor yang mendorong seseorang untuk melakukan aktivitas tertentu, salah satunya yaitu motivasi (Sutrisno, 2011).

Siswanto (2007) mengemukakan bahwa penempatan tenaga kerja adalah suatu proses pemberian tugas dan pekerjaan kepada tenaga kerja yang lulus seleksi untuk melaksanakan secara kontinuitas dengan wewenang dan tanggung jawab sebesar porsi dan komposisi yang ditetapkan serta mampu mempertanggungjawabkan segala risiko dan kemungkinan yang terjadi atas fungsi dan pekerjaan, wewenang dan tanggung jawab tersebut.

Veitzhal (2011) menyatakan disiplin kerja merupakan suatu alat yang digunakan para manajer untuk berkomunikasi dengan karyawan agar mereka bersedia untuk mengubah suatu perilaku serta sebagai suatu upaya untuk meningkatkan kesadaran dan kesediaan seseorang mentaati 
semua peraturan dan norma-norma sosial yang berlaku.

Selain penempatan kerja dan disiplin, dalam meningkatkan kinerja seorang karyawan harus memiliki disiplin kerja, hal tersebut untuk menunjukkan keberadaan mereka dalam organisasi. Disiplin kerja adalah suatu alat yang digunakan para pimpinan untuk berkomunikasi dengan karyawan agar mereka bersedia untuk mengubah suatu prilaku serta sebagai suatu upaya untuk meningkatkan kesadaran dan kesediaan seseorang mentaati semua peraturan. (Rivai, 2011).

Tidak hanya faktor ketrampilan, kemampuan dan penguasaan kerja karyawan yang harus dikembangkan oleh perusahaan untuk meningkatkan kinerja karyawan. Namun perusahaan juga harus memperhatikan pula faktor pemberian kompensasi sebagai salah satu motif bagi karyawan untuk bekerja. Pemberian kompensasi bagi karyawan merupakan kewajiban bagi perusahaan yang harus dipenuhi tepat waktu, dilakukan secara adil dan berdasarkan hasil kerja. Kompensasi merupakan segala sesuatu yang diterima oleh para karyawan sebagai balas jasa untuk kerja mereka. Setiap perusahaan memiliki perbedaan sistem kompensasi, sistem disesuaikan dengan visi, misi, dan tujuannya. Menurut Simamora (2004) kompensasi terdiri dari Kompensasi Finansial (bayaran pokok, bayaran prestasi, bayaran insentif, bayaran tertangguh, program perlindungan, bayaran diluar jam kerja, fasilitas) dan kompensasi Nonfinansial (pekerjaan dan lingkungan kerja)

Kegiatan usaha bank secara
umum merupakan usaha yang
berlandaskan pada kepercayaan
masyarakat. Oleh karena itu
profesionalisme pengelola yang
berkecimpung di dalamnya merupakan

suatu keharusan yang tidak bisa ditawar lagi. Keberhasilan suatu organisasi mencapai visi dan misinya sangat ditentukan oleh kinerja sumber daya manusia yang ada di dalamnya. Kinerja organisasi tergantung pada kinerja individu atau dengan kata lain kinerja individu akan memberikan kontribusi pada kinerja organisasi. Artinya perilaku anggota organisasi baik secara individu maupun kelompok, memberikan kekuatan atas kinerja organisasi

PT. BTN (persero) Tbk kantor cabang Palembang merupakan salah satu bank umum pemerintah yang berkembang pesat di kota Palembang. Bank BTN turut mendukang program otoritas jasa keuangan (OJK) dalam pengembangan berbagai jenis produk tidak hanya produk penyediaan rumah bagi masyarakat yang selama ini menjadi produk andalan BTN. Selain itu BTN juga memiliki berbagai produk lain yang mendukung produk andalan. $\mathrm{Hal}$ di atas tentunya membutuhkan kerjasama yang baik dan keras dari seluruh karyawan BTN. Nasabah harus tetap dipertahankan dalam jangka panjang bukan hanya untuk membuka rekening tapi tidak pernah menambah nominal rekening. Untuk dapat menunjukkan kredibilitas BTN di kalangan masyarakat dapat ditunjukkan melalui pelayanan maksimal karyawan. Karyawan yang bekerja maksimal/ berkinerja butuh dukungan dalam bentuk motivasi dan kompensasi.

Karyawan PT. BTN (persero) Tbk kantor cabang Palembang dituntut untuk terus meningkatkan kinerja melalau peningkatan pendidikan dan prestasi. Sifat kerja yang monoton dan tuntutan pekerjaan yang padat membuat karyawan berprinsip yang penting menyelesaikan pekerjaan, karyawan sangat pelit ide dan inovasi dalam bekerja. Meskipun pimpinan 
memotivasi bawahan agar bersemangat dalam bekerja, mengingat target pemerintahan Jokowi yang menetapkan agar merealisasikan program sejuta rumah untuk rakyat dan pemerintah merangkul bank pelat merah yaitu PT Bank Tabungan Negara (BTN) sebagai penggerak utama. Hal tersebut seakan menjadi beban dalam bekerja karena pencapaian target tersebut tidak berdampak pada pengembangan karir karyawan.

Penelitian ini ingin membuktikan penelitian terdahulu yang dilakukan Simamarta (2018) berjudul pengaruh rekruitmen dan penempatan kerja terhadap kinerja karyawan pada Alpha Hotel Pekanbaru. Abdillah (2011) berjudul pengaruh kepemimpinan, stres kerja, disiplin kerja dan kompensasi dengan kinerja pegawai KPP Pratama Boyolali, juga Sahanggamu (2014) berjudul pengaruh pelatihan kerja, motivasi dan disiplin kerja terhadap kinerja karyawan PT. Bank Perkreditan Rakyat Dana Raya. Firmandari (2014) pengaruh kompenassi terhadap kkinerja karyawan dengan motivasi kerja sebagai variabel moderasi (studi pada Bank syariah Mandiri Kantor Cabang Yogjakarta).

Berdasarkan uraian di atas peneliti mengkaji lebih mendalam melalui penelitian berjudul penempatan kerja, disiplin kerja dan kompensasi terhadap kinerja karyawan PT. Bank Tabungan Negara (Persero) Tbk Cabang Palembang.

\section{B. Landasan Teori}

1) Kinerja

Prawirosentono (2015) kinerja/ performance yaitu hasil kerja yang dapat dicapai oleh seseorang atau sekelompok orang dalam suatu organisasi, sesuai dengan wewenang dan tanggung jawab masing-masing, dalam rangka upaya mencapai tujuan organisasi bersangkutan secara legal, tidak melanggar hukum dan sesuai dengan moral maupun etika. Mangkunegara (2005), indikator yang dapat digunakan untuk mengukur kinerja pegawai yaitu dengan melihat hasil kerjanya secara kualitas maupun kuantitas yang dicapai oleh seorang pegawai dalam melaksanakan tugasnya sesuai dengan tanggung jawab yang diberikan kepadanya.

1. Kualitas kerja, pegawai yang memiliki kinerja yang baik, maka dapat dilihat dari kualitas kerja, akurasi kerja, dan marginal kesalahan.

2. Kuantitas Kerja, pegawai selalu berusaha untuk menyelesaikan tugas dengan hasil yang benar, maksimal, dan tepat waktu.

3. Tanggung Jawab, pegawai bertanggung jawab dalam menyelesaikan tugas-tugas, memiliki rencana kerja yang jelas, berusaha untuk merealisasikan rencana kerja.

2) Penempatan Kerja

Salah satu fungsi manajemen SDM untuk mengurus penempatan kerja (Work Placement). Penempatan kerja berarti mengalokasikan karyawan pada posisi tertentu, hal ini khusus pada karyawan baru. Bagi karyawan lama yang telah menduduki posisi atau jabatan tertentu sasaran penempatan dalam arti mempertahankan posisnya atatu memindahkan ke posisi yang lain. Penempatan kerja merupakan suatu proses pemberian tugas dan pekerjaan kepada karyawan yang lulus dalam seleksi untuk melaksanakan tugasnya dengan kontinuitas dan tanggung jawab. Penempatan karyawan berarti mengalokasikan karyawan pada posisi tertentu (khusus karyawan baru). Penempatan kerja berlaku bagi karyawan lama yang telah menduduki pekerjaan atau jabatan 
tertentu sasarannya adalah mempertahankan kedudukan atau pindah pada posisi lain (Rivai, 2011). Ada beberapa faktor yang harus dipertimbangkan dalam penempatan karyawan antara lain, faktor prestasi akademis, faktor pengalaman, faktor kesehatan fisik dan mental, faktor sikap, faktor situasional, faktor motivasi dan faktor kesempatan (Siswanto, 2007).

3) Disiplin Kerja

Hasibuan (2017) menyatakan kedisiplinan adalah kesadaran dan kesediaan seseorang mentaati semua peraturan perusahaan dan normanorma sosial yang berlaku. Selanjutnya Komarudin (2005) menyatakan disiplin adalah suatu keadaan tenaga kerja yang berada di dalam organisasi, organisasi pemerintah maupun swasta, harus dapat memenuhi peraturan dan tata tertib yang berlaku dalam organisasi maupun instansi baik secara tertulis maupun tidak dengan tujuan agar supaya semua kegiatan berjalan dengan baik. Menurut Gibson (2006) disiplin adalah proses mempengaruhi karyawan dalam mentaati semua peraturan perusahaan yang ada dalam perusahaan atau setiap tingkah laku dan perbuatan yang sesuai dengan peraturan perusahaan baik yang tertulis maupun yang tidak tertulis.

Menurut McClelland (2004) tindakan disiplin ini dapat berupa teguran-teguran (reprimands), penskoran (Suspension), penurunan pangkat atau gaji (reductions in rank or pay) dan pemecatan (firing). Tindakan disiplin ini tidak termasuk pemberhentian sementara atau penurunan jumlah tenaga kerja yang disebabkan oleh pengurangan anggaran atau kurangnya kerja. Tindakan-tindakan disipliner ini disebabkan oleh kejadian-kejadian perilaku khusus dari karyawan yang menyebabkan rendahnya produktivitas atau pelanggaran-pelanggaran aturanaturan instansi. Menurut Rivai (2011) disiplin kerja adalah suatu alat yang digunakan para manajer untuk berkomunikasi dengan karyawan agar mereka bersedia untuk mengubah suatu prilaku serta sebagai suatu upaya untuk meningkatkan kesadaran dan kesediaan seseorang mentaati semua peraturan perusahaan dari norma-norma sosial yang berlaku.

\section{4) Kompensasi Hasibuan}

(2017:119) Kompensasi adalah semua pendapatan yang berbentuk uang, barang langsung atau tidak langsung yang diterima karyawan sebagai immbalan atas jasa yang diberikan kepada perusahaan. Pembentukan sistem kompensasi yang efektif merupakan bagian penting dari manajemen sumber daya manusia karena membantu menarik dan mempertahankan pekerjaan-pekerjaan yang berbakat. Selain itu sistem kompensasi perusahaan memiliki dampak terhadap kinerja strategis. Dari beberapa kompensasi tersebut, kompensasi uang adalah kompensasi yang dibayar dengan sejumlah uang kartal kepada yang bersangkutan. Sedangkan kompensasi barang adalah kompensasi yang diberikan dalam bentuk barang, misalnya $10 \%$ dari hasil produksi. Kompensasi adalah bentuk pembayaran dalam bentuk manfaat dan insentif untuk memotivasi karyawan agar produktifitas kerja semakin meningkat (Yani,2012). Menurut Rivai (2011) kompensasi merupakan sesuatu yang diterima pegawai sebagai pengganti kontribusi jasa mereka pada perusahaan. Menurut Handoko (2009) kompensasi adalah pemberian pembayaran finansial kepada pegawai sebagai balas jasa untuk pekerjaan yang 
dilaksanakan dan sebagai motivator pelaksana kegiatan yang akan datang.

\section{Populasi dan Sampel}

1) Populasi

Populasi menurut Sugiyono (2014) adalah wilayah generalisai yang terdiri dari obyek atau subyek yang mempunyai kualitas dan karakteristik tertentu yang ditetapkan oleh peneliti untuk mempelajari dan ditarik kesimpulannya. Populasi yang akan dijadikan sumber dalam penelitian ini adalah 141 orang karyawan Tetap PT. Bank tabungan Negara Tbk. Kantor Cabang Palembang pada kantor cabang dan perpanjangan jaringan kantor cabang (kantor cabang pembantu dan kantor kas).
2) Sampel

Sampel adalah bagian dari jumlah dan karakteristik yang dimiliki oleh populasi. Dihitung dengan rumus Isaac dan Michael untuk populasi sebesar 141 orang dengan tingkat kesalahan 5\% maka jumlah sampel sebanyak 103 orang. Teknik sampling pada penelitian ini adalah probability sampling dengan tipe cluster sampling yaitu tehnik yang digunakan untuk menentukan sampel bila obyek yang akan diteliti atau data sumber sangat luas.

\section{Kerangka Berpikir}

Berdasarkan uraian di atas, maka kerangka pemikiran dalam penelitian ini adalah:

Gambar 1

Kerangka Pemikiran

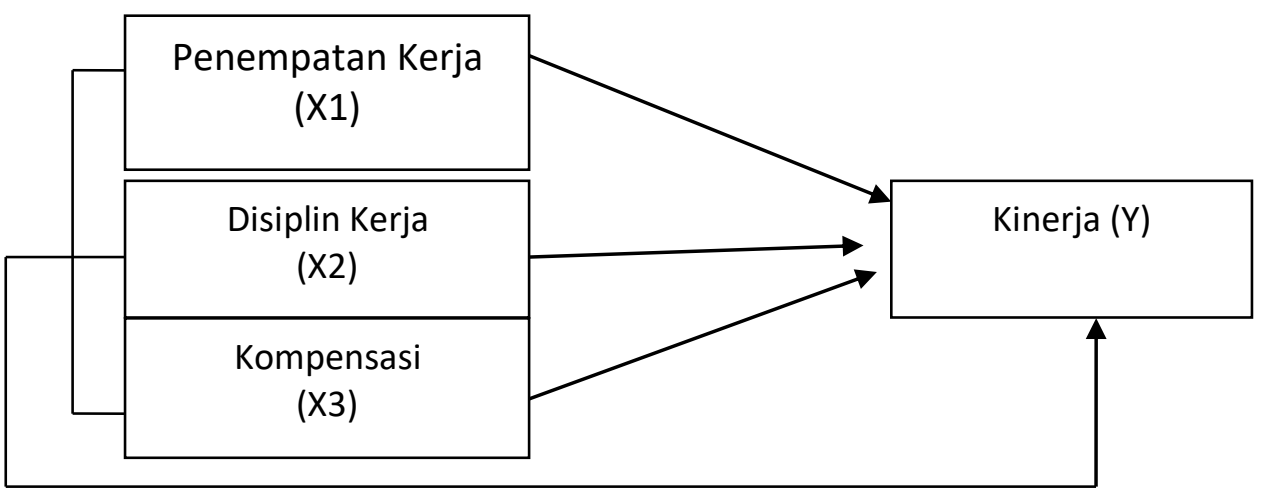

\section{E. Hasil Penelitian}

\section{Analisis Regresi Linear Berganda}

Dalam menganalisis pengaruh penempatan kerja, disiplin kerja dan kompensasi terhadap kinerja digunakan analisis regresi berganda. Hasil pengolahan data dengan menggunakan SPSS ditampilkan pada Tabel berikut ini :

Tabel 1. Hasil Uji Regresi Linear Berganda

\begin{tabular}{|c|c|c|c|}
\hline \multirow[b]{2}{*}{ Model } & \multicolumn{2}{|c|}{$\begin{array}{l}\text { Unstandardized } \\
\text { Coefficients }\end{array}$} & $\begin{array}{l}\text { Standardized } \\
\text { Coefficients }\end{array}$ \\
\hline & $B$ & Std. Error & Beta \\
\hline 1 (Constant) & 1,261 & 0,366 & \\
\hline Penempt.Krj & 0,434 & 0,092 & 0,459 \\
\hline Disiplin.Krj & 0,266 & 0,088 & 0,334 \\
\hline Kompensasi & 0,285 & 0,054 & 0,277 \\
\hline
\end{tabular}

Sumber: Hasil Perhitungan data sekunder, 2018 
Berdasarkan hasil perhitungan pada Tabel 1, maka estimasi fungsi regresi diperoleh adalah sebagai berikut:

$Y=1,261+0,434 X_{1}+0,266 X_{2}+0,285 X_{3}$

Nilai konstanta sebesar 1,261 menunjukkan bahwa kinerja karyawan tetap ada meskipun tanpa penempatan kerja, disiplin kerja, dan kompensasi. Penempatan kerja sebesar 0,434 (positif) artinya jika ada peningkatan terhadap penempatan kerja $\left(\mathrm{X}_{1}\right)$ sebesar satu satuan skor maka kinerja juga akan meningkat, sebaliknya jika ada penurunan terhadap penempatan kerja $\left(X_{1}\right)$ sebesar satuan skor, maka akan menurunkan kinerja $(Y)$ sebesar 0,434 satuan skor. Disiplin kerja sebesar 0,266 (positif) artinya jika ada peningkatan terhadap disiplin kerja $\left(X_{2}\right)$ sebesar satu satuan skor, maka kinerja juga meningkat, sebaliknya jika ada penurunan terhadap disiplin kerja
$\left(X_{2}\right)$ sebesar satu satuan skor, maka akan menurunkan kinerja sebesar 0,266 satuan skor. Kompensasi sebesar 0,285 (positif) artinya jika ada peningkatan terhadap kompensasi $\left(X_{3}\right)$ sebesar satu satuan skor, maka kinerja juga meningkat, sebaliknya jika ada penurunan terhadap kompensasi $\left(X_{3}\right)$ sebesar satu satuan skor, maka akan menurunkan kinerja sebesar 0,285 satuan skor.

\section{Hasil Uji Determinan $\left(\mathbf{R}^{2}\right)$}

Pengujian koefisien determinasi digunakan untuk mengetahui seberapa besar kontribusi variabel bebas dapat menjelaskan variabel terikat. Nilai koefisien determinan dilihat dari nilai $R$ Square $\left(R^{2}\right)$. Dimana jika nilai $R$ Square sama dengan nol, maka tidak ada sedikit pun pengaruh yang diberikan variabel bebas terhadap variabel terikat.

Tabel 2. Hasil Uji Determinant

\begin{tabular}{|l|r|r|r|r|}
\hline $\begin{array}{l}\text { Mode } \\
\mathrm{I}\end{array}$ & $\mathrm{R}$ & $\mathrm{R}$ Square & $\begin{array}{c}\text { Adjusted R } \\
\text { Square }\end{array}$ & $\begin{array}{c}\text { Std. Error of } \\
\text { the Estimate }\end{array}$ \\
\hline 1 & $0,590^{\mathrm{a}}$ & 0,449 & 0,429 & 0,42377 \\
\hline
\end{tabular}

Hasil pengujian determinasi menunjukkan nilai sebesar 0,449 $(44,9 \%)$ artinya variabel terikat dapat dijelaskan oleh variabel independen sebesar $44,9 \%$ sisanya sebesar $54,1 \%$ dijelaskan oleh variabel lain yang tidak masuk dalam penelitian ini.

Tabel 3. Hasil Hipotesis Uji F

\begin{tabular}{|c|c|c|c|c|c|}
\hline Model & $\begin{array}{l}\text { Sum of } \\
\text { Squares }\end{array}$ & Df & $\begin{array}{c}\text { Mean } \\
\text { Square }\end{array}$ & $F$ & Sig. \\
\hline 1 Regression & 7,546 & 3 & 3,156 & 17,655 & $0,000^{a}$ \\
\hline Residual & 13,697 & 99 & 0,179 & & \\
\hline Total & 22,153 & 102 & & & \\
\hline
\end{tabular}

Sumber: Hasil Perhitungan data sekunder, 2018

\section{Uji Hipotesis F (uji simultan)}

Uji $F$ digunakan untuk menguji pengaruh variabel penempatan kerja, disiplin kerja dan kompensasi terhadap kinerja karyawan. 
Berdasarkan hasil perhitungan regresi linear berganda diperoleh nilai sig $F(0,000)<\operatorname{Sig} \alpha(0,05)$ maka $\mathrm{H}_{0}$ ditolak artinya penempatan kerja, disiplin kerja dan kompensasi mempunyai pengaruh signifikan terhadap kinerja karyawan.

\section{Uji Hipotesis t (uji parsial)}

Uji hipotesis $\mathrm{t}$ digunakan untuk melihat tingkat signifikansi masingmasing koefisien regresi.

Tabel 4. Hasil Hipotesis Uji t

\begin{tabular}{|c|r|r|}
\hline Model & $\mathrm{t}$ & \multicolumn{1}{c|}{ Sig. } \\
\hline 1 (Constant) & 0,565 & 0,643 \\
Penempat.krj & 3,063 & 0,041 \\
Disiplin.Krj & 2,352 & 0,010 \\
Kompensasi & 2,431 & 0,021 \\
\hline \multicolumn{2}{|c|}{ Sumber: Hasil Perhitungan SPSS versi 19, Tahun 2017 }
\end{tabular}

Berdasarkan hasil perhitungan uji koefisien regresi pada Tabel 4. Variabel penempatan kerja sig $\mathrm{t}$ $(0,041)<\alpha(0,05)$, maka H0 ditolak artinya terdapat pengaruh positif dan signifikan penempatan kerja terhadap kinerja. Variabel disiplin kerja dengan nilai sig $\mathrm{t}(0,010)<\alpha(0,05)$, maka $\mathrm{H} 0$ ditolak artinya disiplin kerja mempunyai pengaruh positif dan signifikan terhadap kinerja. Variabel kompensasi diperoleh nilai sig $t(0,021)<\alpha(0,05)$, maka $\mathrm{H} 0$ ditolak artinya kompensasi mempunyai pengaruh positif dan signifikan terhadap kinerja karyawan.

\section{F. Pembahasan}

Pengaruh Penempatan kerja, Disiplin Kerja dan Kompensasi terhadap Kinerja Karyawan PT. BTN (Persero) Tbk Kantor Cabang Palembang.

Berdasarkan hasil uji $\mathrm{F}$ dipeoleh nilai signifikan $F(0,000)<$ Sig $\alpha(0,05)$. Hal tersebut menunjukkan bahwa ada pengaruh positif dan signifikan penempatan kerja dan disiplin kerja serta kompensasi secara simultan terhadap kinerja karyawan. Dengan demikian, hipotesis penelitian yang menyatakan bahwa ada pengaruh signifikan penempatan kerja dan disiplin kerja serta kompensasi terhadap kinerja karyawan PT. BTN (Persero) Tbk. Kantor cabang Palembang, dapat diterima.

Penempatan kerja di PT. BTN belum berjalan sebagaimana mestinya karena rekruitmen karyawan tidak disesuaikan dengan latar belakang pendidikan, penerimaan karyawan untuk bagian teller dan costumer service mestinya dari disiplin ilmu ekonomi atau ilmu akuntansi, tapi penerapannya berbagai ilmu mampu menjalankan aktivitas di perbankan.

Namun penyelesaian pekerjaan di awal bekerja mungkin tidak seefektif karyawan yang memiliki latar belakang pendidikan. Tingginya volume pekerjaan mengharuskan karyawan menjadi cekatan dan profesional sehingga akhirnya menjadi terbiasa.

Penelitian ini memberikan rekomendasi dan sejalan dengan penelitian yang dilakukan Tindow (2014) berjudul disiplin kerja, motivasi dan kompensasi pengaruhnya terhadap kinerja karyawan pada PT. Bank SULUT Cabang Calaca. Hasil 
penelitiannya menunjukkan bahwa disipli kerja, motivasi dan kompensasi berpengaruh positif dan signifikan terhadap kinerja karyawan.

\section{Pengaruh Penempatan kerja terhadap Kinerja Karyawan PT. BTN (Persero) Tbk Kantor Cabang Palembang.}

Berdasarkan hasil uji koefisien variabel penempatan kerja diperoleh nilai signifikan $t(0,041)<$ Sig $\alpha(0,05)$. Hal tersebut menunjukkan bahwa ada pengaruh positif dan signifikan penempatan kerja terhadap kinerja karyawan. Dengan demikian, hipotesis penelitian yang menyatakan bahwa ada pengaruh signifikan penempatan terhadap kinerja karyawan PT. BTN (Persero) Tbk. Kantor cabang Palembang, dapat diterima.

Hal itu menunjukkan bahwa selama ini ketidaksesuaian latar belakang pendidikan karyawan pada suatu bidang tidak menganggu karyawan dalam bekerja, justru karyawan membutuhkan pengalaman kerja. Berada dalam suatu bidang dalam waktu yang lama mampu membuat mereka menguasai pekerjaan meskipun tidak sesuai dengan latar belakang pendidikan akademis.

\section{Pengaruh Disiplin Kerja terhadap Kinerja Karyawan PT. BTN (Persero) Tbk Kantor Cabang Palembang.}

Berdasarkan hasil uji koefisien variabel disiplin kerja diperoleh nilai $\mathrm{t}$ hitung $(2,642)>t$ tabel $(1,984)$ atau sig $t(0,010)<$ Sig $\alpha(0,05)$. Hal tersebut menunjukkan bahwa ada pengaruh positif dan signifikan disiplin kerja terhadap kinerja karyawan. Dengan demikian, hipotesis penelitian yang menyatakan bahwa ada pengaruh signifikan disiplin kerja terhadap kinerja karyawan PT. BTN (Persero) Tbk. kantor cabang Palembang, dapat diterima.

Disiplin kerja karyawan PT. BTN cabang Palembang masih cukup baik karyawan memiliki tujuan dan kemampuan dalam bekerja. PT. BTN memperlakukan karyawan secara adil dalam pemberian tugas. Pimpinan aktif melakukan pengawasan. Karyawan yang melanggar peraturan diberikan sanksi sesuai peraturan. Pimpinan memberikan sanksi yang tegas kepada bawahan yang melanggar peraturan. Pimpinan memiliki hubungan yang baik dengan masyarakat dan masyarakat. Tanggapan kesetujuan yang tinggi menunjukkan disiplin kerja karyawan yang cukup baik, berdampak pada tanggapan karyawan untuk variabel kinerja karyawan. Karyawan menghasilkan pekerjaan dengan kualitas baik, hal ini disebabkan karyawan memiliki keahlian yang memadai terkait pekerjaan, sehingga pekerjaan yang dihasilkan maksimal tanpa komplain dari pimpinan dan nasabah. Karyawan menyelesaikan pekerjaan sesuai target dan menyelesaikan semua tugas pokok mapupun tugas tambahan yang diberikan pimpinan. Karyawan juga mampu menghasilkan pekerjaan di atas standar umum.

Disiplin kerja adalah proses mempengaruhi karyawan dalam mentaati semua peraturan perusahaan yang ada dalam perusahaan atau setiap tingkah laku dan perbuatan yang sesuai dengan peraturan perusahaan baik yang tertulis maupun yang tidak tertulis. Disiplin dapat terwujud jika karyawan memiliki tujuan dan kemampuan dalam bekerja, teladan pimpinan, pengawasan dan ketegasan pimpinan dalam membuat peraturan. Selain itu adanya gaji yang sesuai dengan beban kerja yang dilakukan karyawan. Jika semua itu 
terpenuhi maka karyawan akan memiliki kesadaran untuk dalam disiplin yang tinggi dalam bekerja.

Ketatnya tahapan penerimaan karyawan bank membuktikan bahwa karyawan memiliki kemampuan yang baik, karena sampai saat ini penerimaan karyawan bank selalu fair sesuai keahlian dan kemampuan. Konsekuensi bekerja di bank harus mampu bekerja di bawah tekanan dan jam kerja yang lebih dari kantor lain. Ketatnya peraturan dan tegasnya sanksi yang diberikan pimpinan membuat karyawan memiliki disiplin tinggi. Persentase ketidakhadiran karyawan mengikuti breafing morning pada kantor pusat di pagi hari yang tidak lebih dari $70 \%$ saja dari jumlah karyawan, disebabkan kegiatan tersebut hanya ditujukan untuk karyawan bagian pelayanan (teller dan CSO), sedangkan bagian lain tidak dituntut rutin mengikuti tapi dianjurkan mengikutinya.

\section{Pengaruh Kompensasi terhadap Kinerja Karyawan PT. BTN (Persero) Tbk Kantor Cabang Palembang.}

Berdasarkan hasil uji koefisien variabel kompensasi diperoleh nilai signifikan $t(0,021)<$ Sig a $(0,05)$. Hal tersebut menunjukkan bahwa ada pengaruh positif dan signifikan kompensasi terhadap kinerja karyawan. Dengan demikian, hipotesis penelitian yang menyatakan bahwa ada pengaruh signifikan kompensasi terhadap kinerja karyawan PT. BTN (Persero) Tbk. Kantor cabang Palembang, dapat diterima.

Kompensasi yang diterima karyawan PT. BTN cabang Palembang sudah baik dilihat pada tanggapan responden yang menyatakan menerima gaji yang sesuai dengan Upah Minimum Provinsi (UMP). Karyawan mendapat upah yang sesuai dengan tambahan tugas. Karyawan merasa sejahtera telah menjadi bagian personil PT. BTN. Kompensasi yang diterima karyawan sudah sesuai dengan standar penggajian. Karyawan menghasilkan pekerjaan dengan kualitas baik, hal ini disebabkan karyawan memiliki keahlian yang memadai terkait pekerjaan, sehingga pekerjaan yang dihasilkan maksimal tanpa komplain dari pimpinan dan nasabah. Karyawan menyelesaikan pekerjaan sesuai target dan menyelesaikan semua tugas pokok mapupun tugas tambahan yang diberikan pimpinan. Karyawan juga mampu menghasilkan pekerjaan di atas standar umum. Kompensasi adalah semua pendapatan yang berbentuk uang, barang langsung atau tidak langsung yang diterima karyawan sebagai imbalan atas jasa yang diberikan oleh perusahaan. Kompensasi dapat berupa kompensasi uang adalah kompensasi yang dibayar dengan sejumlah uang kartal kepada yang bersangkutan. Sedangkan kompensasi barang adalah kompensasi yang diberikan dalam bentuk barang, misalnya $10 \%$ dari hasil produksi. Kompensasi adalah bentuk pembayaran dalam bentuk manfaat dan insentif untuk memotivasi karyawan agar produktifitas kerja semakin meningkat.

\section{G. Kesimpulan}

Berdasarkan hasil penelitian dan pembahasan yang dilakukan pada bab sebelumnya, maka penulis memperoleh simpulan pada penelitian ini yaitu sebagai berikut:

1. Ada pengaruh signifikan penempatan kerja, disiplin kerja dan kompensasi secara simultan terhadap kinerja karyawan PT. BTN (persero) Tbk. Kantor cabang Palembang.

2. Ada pengaruh signifikan penempatan kerja, disiplin kerja dan kompensasi secara parsial terhadap 
kinerja karyawan PT. BTN (persero) Tbk. Kantor cabang Palembang.

\section{DAFTAR PUSTAKA}

Agoes, Sukrisno, \& Ardana, I Cenik. (2009). Etika Bisnis dan Profesi, Tantangan Membangun Manusia Seutuhnya. Jakarta, Indonesia: Salemba Empat.

Brahmasari, dan Suprayetno. (2008). Pengaruh Motivasi Kerja, Kepemimpinan dan Budaya Organisasi Terhadap Kepuasan Kerja Karyawan serta Dampaknya pada Kinerja Perusahaan (Studi kasus pada PT. Pei Hai International Wiratama Indonesia). Jurnal manajemen.petra.ac.id. 10 (2), 124-135

Chaidir Abdillah, A dan Wajdi, F. (2011).

Pengaruh Kepemimpinan, Stres Kerja, Disiplin Kerja, dan Kompensasi dengan Kinerja Pegawai pada KPP Pratama di Boyolali. ojs.unud.ac.id. 11 (01),1-11.

Firmandari, Nuraini (2014). Pengaruh Kompensasi terhadap Kinerja Karyawan dengan Motivasi Kerja sebagai Variabel Moderasi (studi pada Bank Syariah Mandiri Kantor Cabang Yogjakarta). Jurnal Ekbisi Vol.IX No.1 Desember 2014. Hal: 2534

Gibson. (2006). Perilaku Organisasi. Buku 1. Edisi Kedua Belas. Alih Bahasa Diana Angelina 2007. Jakarta, Indonesia: Salemba Empat
Handoko T, Hani. (2009). Manajemen Personalia dan SDM (Edisi 2). Yogyakarta, Indonesia: BPFE.

Hasibuan, SP Malayu. (2017). Manajemen Sumber Daya Manusia (Edisi Revisi). Jakarta, Indonesia: Bumi Aksara.

Lunenburg, Orstein. (2011). Educational Administration. Singapura: Wadworth.

Mangkunegara, Prabu, Anwar. (2005). Manajemen SDM Perusahaan, Bandung, Indonesia: Remaja Rosdakarya

Masngudi \& Noor Salim, M. (2012). Metodologi Penelitian Untuk Ekonomi dan Bisnis, Jakarta, Indonesia: Trianandra University Press.

Muhamad. (2008). Metode Penelitian Ekonomi Islam Pendekatan Kuantitatif. Jakarta, Indonesia: Raja Grafindo.

Prawirosentono, Suyadi., \& Primasari, Dewi. (2015). Manajemen Sumberdaya Manusia Kinerja \& Motivasi Karyawan, Membangun Organisasi Kompetitif Era Perdagangan Bebas Dunia (Edisi Ketiga). Yogyakarta, Indonesia: BPFE-Yogyakarta.

Priyatno, Dwi. (2008). Mandiri Belajar SPSS Untuk Analisis dan Uji Statistik. Jakarta, Indonesia: Gramedia Pustaka Utama.

Riduwan. (2009). Pengantar Statistik Pendidikan, Sosial, Ekonomi, Komunikasi dan Bisnis. (cet.3). Bandung, Indonesia: Alfabeta.

Rivai, Veitzhal. (2011). Manajemen Sumber Daya Manusia untuk 
Perusahaan. Jakarta, Indonesia: Rajawali Pers.

Robert, L, Malthis. (2002), Human Resources Management. Jakarta, Indonesia: Salemba Empat

Sahanggamu, Patricia, \& Mandey, Silvya. (2014). Pengaruh Pelatihan Kerja, Motivasi dan Disiplin Kerja terhadap Kinerja Karyawan Pada PT. Bank Perkreditan Rakyat Dana Raya. Jurnal Ekonomi Manajemen Bisnis dan Administrasi. 2 (4), 514-523.

Simamarta, Sariwati (2018). Pengaruh Rekruitmen dan Penempatan Kerja terhadap Kinerja Karyawan pada Alpha Hotel Pekanbaru. JOM Fisip Vol.5 (1) April 2018. Diakses: https://Jom.unri.ac.id/index.php/ JOMFSIP/article/viewfilo/16707

Siswanto. (2007). Pengantar Manajemen. (cet.3). Jakarta, Indonesia: Bumi Aksara.

Siti Masitoh, D (2013). Pengaruh Budaya Organisasi dan Kompensasi terhadap Motivasi Kerja serta Implikasinya terhadap Kinerja Karyawan di PT. BTN Cabang Bandung. ejournal.upi.edu. 04 (01), 1-19.
Sugiyono. (2014). Metode Penelitian Bisnis. Edisi 18. Bandung, Indonesia: Alfabeta.

Sunyoto, Danang. (2015). Penelitian Sumber Daya Manusia. Jakarta, Indonesia: CAPS (Center of Academic Publishing Service).

Sutrisno, Edy. (2011). Manajemen Sumber Daya Manusia. Jakarta, Indonesia: Kencana

Tindow, Iman M \& Mekel, Peggy.(2014). Disiplin Kerja, Motivasi dan Kompensasi terhadap Kinerja Karyawan pada Bank SULUT Cabang Calaca. Jurnal Ekonomi Manajemen Bisnis dan Administrasi. 2 (2), 1594-1606.

Wibowo. (2008). Manajemen Kinerja. (ed.3). Jakarta, Indonesia: RajaGrafindo Persada.

Wibisono, D. (2006). Manajemen Kinerja: Konsep, Desain, dan Teknik Meningkatkan Daya Saing Perusahaan. Jakarta, Indonesia: Erlangga.

Widodo Eko, Suparno. (2015). Manajemen Pengembangan Sumber Daya Manusia. Yogyakarta, Indonesia: Pustaka Pelajar. 